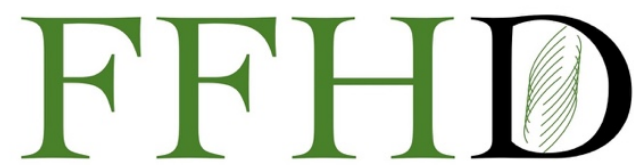

Functional Foods in Health and Disease

\title{
Solvent extraction and spectroscopy identification of bioactive compounds from medicinal shrub Tamarix gallica
}

\section{Moussa Mohammed Elamin}

Faculty of chemistry, Department of Exact Sciences, University of Tahri Mohamed; Bechar, Algeria

Corresponding author: Moussa Mohammed Elamin, PhD, Faculty of chemistry, Department of Exact Sciences, University of Tahri Mohamed; Bechar, Algeria.

Submission Date: August 14 ${ }^{\text {th }}, 2020$; Acceptance Date: October 28 ${ }^{\text {th }}, 2020$; Publication Date: November $17^{\text {th }}, 2020$

Please cite this article as: Elamin M.M., Solvent extraction and spectroscopy identification of bioactive compounds from Medicinal Shrub Tamarix gallica. Functional Foods in Health and Disease 2020. 10(11): 456-464. DOI: https://www.doi.org/10.31989/ffhd.v10i11.744

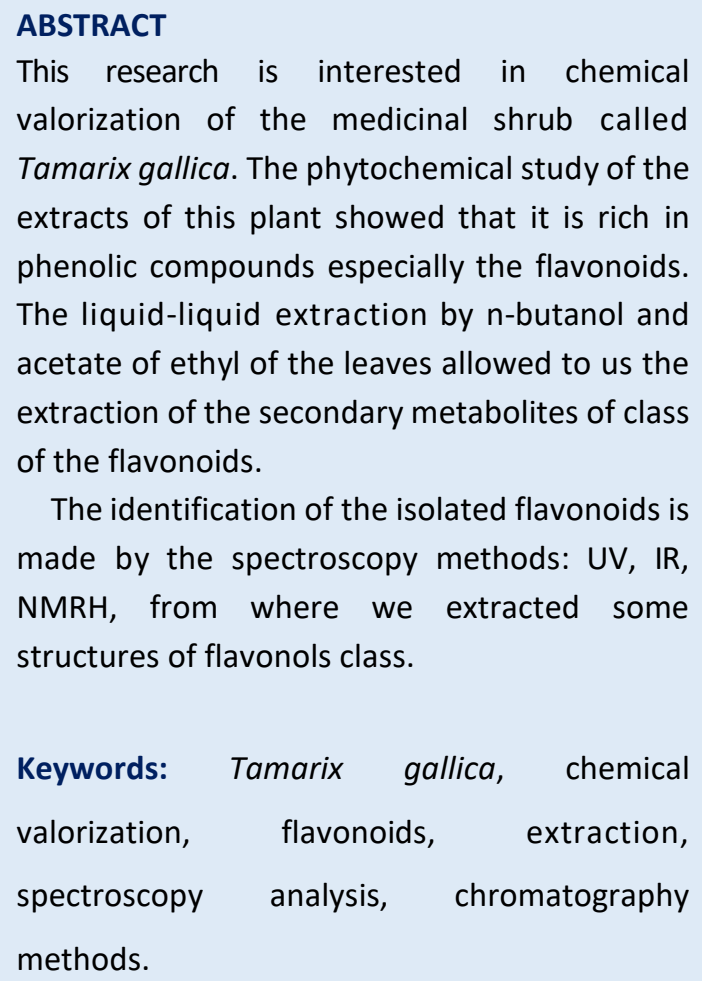

The identification of the isolated flavonoids is made by the spectroscopy methods: UV, IR, $\mathrm{NMRH}$, from where we extracted some structures of flavonols class.

Keywords: Tamarix gallica, chemical valorization, flavonoids, extraction, spectroscopy analysis, chromatography methods.

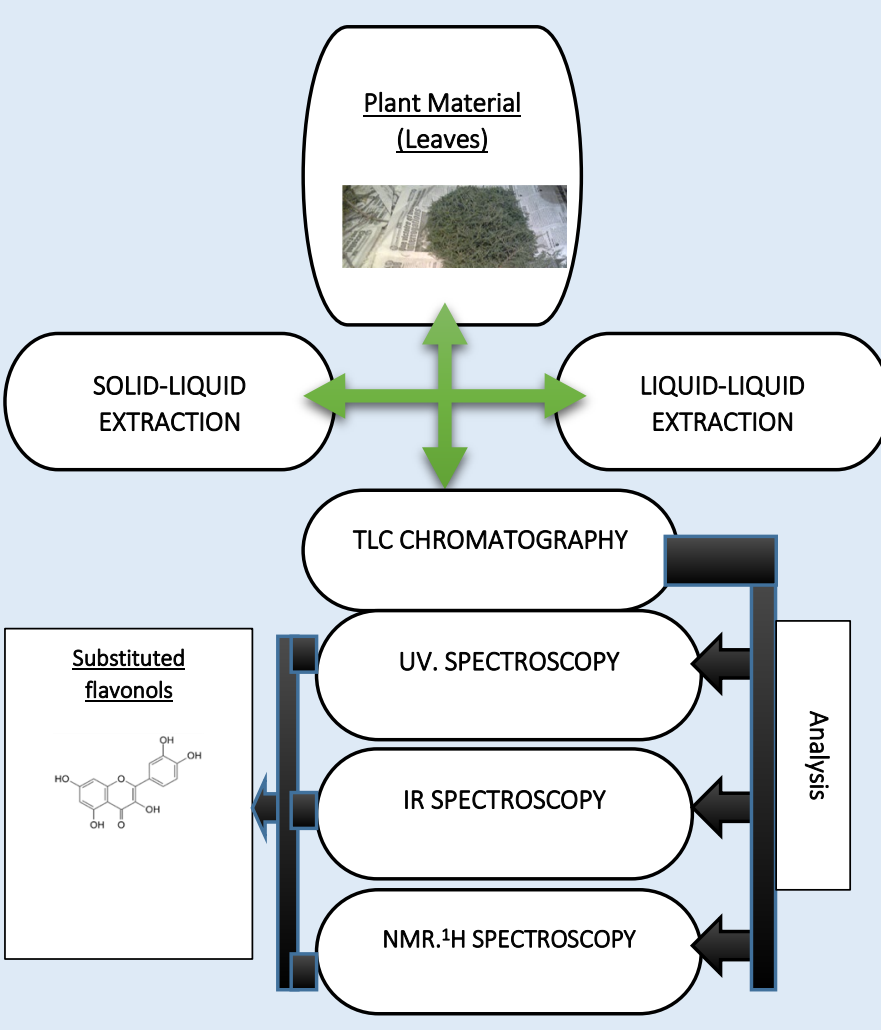

CFFC 2020. This is an Open Access article distributed under the terms of the Creative Commons Attribution 4.0 License (http://creativecommons.org/licenses/by/4.0) 


\section{INTRODUCTION}

The African continent is rich with a biodiversity of plants, including a high number of plants used as herbs for natural foods and therapeutic purposes. Tamarix species are employed in traditional medicine as astringent, aperitif, stimulus of perspiration and diuretic. It is used as anthelmintic, anti-hemorrhoid hemostats and for diarrhea and gingivitis. The plant is used to cure dromedary galls. Several researches have proved antioxidant and antimicrobial activities of Tamarix species such as $T$. ramosissima and $T$. hispida. In Algeria and surrounding areas, the plant has been used medicinally for rheumatism, diarrhea, and other maladies. Vegetable and fruit peels of the plant are used as a novel source of antioxidant. Antimicrobial activity of Tamarix gallica has also been reported. It can be used as a prophylactic and a therapeutic remedy to cure malaria as folk medicine. The bark is bitter and an astringent, tonic; fruit and roots are useful for dysentery and chronic diarrhea. The manna produced on the plant is detergent, expectorant and laxative. The sweet and mucilaginous manna is believed to be produced by exudation from the insects. Galls produced on the plant as a result of insect damage are astringent [1]

Tamarix species are ornamental bushes or trees with feathery foliage, mostly evergreen with pink or white blossoms. They are relatively long-lived plants that can tolerate a wide range of environmental conditions and resist biotic stresses such as high temperature, salt, and drought stresses. Tamarix prefer alluvial soil but grow well on saline and alkaline soil. It grows in semi-arid localities, growing to 17 to 19 feet tall, and is recognized by its stringy appearance. The smooth, reddish-brown bark of younger plants becomes brownish-purple, ridged, and furrowed as they age. Masses of small, pink flowers blossom on the ends of its branches from June to August. The leaves are scale-like, 1-2 mm long, and overlap each other along the stem. They are often encrusted with salt secretions. The pink to white flowers appear in dense masses on 5-10 cm long spikes at branch tips from March to September, though some species (e.g. T. aphylla) tend to flower during the winter. Tamarix can spread both vegetative, by adventitious roots and submerged stems, and sexually, by seeds. Each flower can produce thousands of tiny about $1 \mathrm{~mm}$ diameter seeds that are contained in a small capsule usually adorned with a tuft of hair that aids in wind dispersal. Seeds can also be dispersed by water. Seedlings require extended periods of soil saturation for establishment. Tamarix species are fire-adapted and have long tap roots that allow them to intercept deep water tables and exploit natural water resources. They are able to limit competition from other plants by taking up salt from deep ground water, accumulating it in their foliage, and from there depositing it in the surface soil where it builds up concentrations temporarily detrimental to some plants [2]. The salt is washed away during heavy rains. Tamarix trees are most often propagated by cuttings. Tamarix species are used as food plants by the larvae of some Lepidoptera species including Coleophora asthenella which feeds exclusively on $T$. africana. Resin of Tamarix gallica, when it melts in the sun, is similar to wax, is sweet and aromatic (like honey), and has a dirty-yellow color, fitting somewhat with the Biblical descriptions of manna. This plant makes a good fuel [3].

The objective of our work targets the extraction and identification of biologically active substances of the species Tamarix gallica. This study contains two main parts:

- The first part describes the methods and materials used in experimental (phytochemical screening, protocol of extraction and chromatographic methods and spectroscopy methods).

- The second part represents the results of the species to be studied and the results of the extraction of secondary metabolites from the leaves and the interpretation of UV spectra, IR and NMR of the isolated compounds [4-5]. 


\section{MATERIALS AND METHODS}

Collection of Plant material: The collection of the shrub of Tamarix gallica has been carried out on the month of February, from 06/02/2015 to 08/02/2015 at the level of the city of Bechar, next to the valley of Bechar, which is located near the district of Djenain
Difallah. It was flushed by ordinal water and the leaves were dried, and then the leaves were put away in a dark and dry place for 10-15 days. After that we grinded them to aid a mill to form a little fine powder, and we retained it in a well closed glass vial.
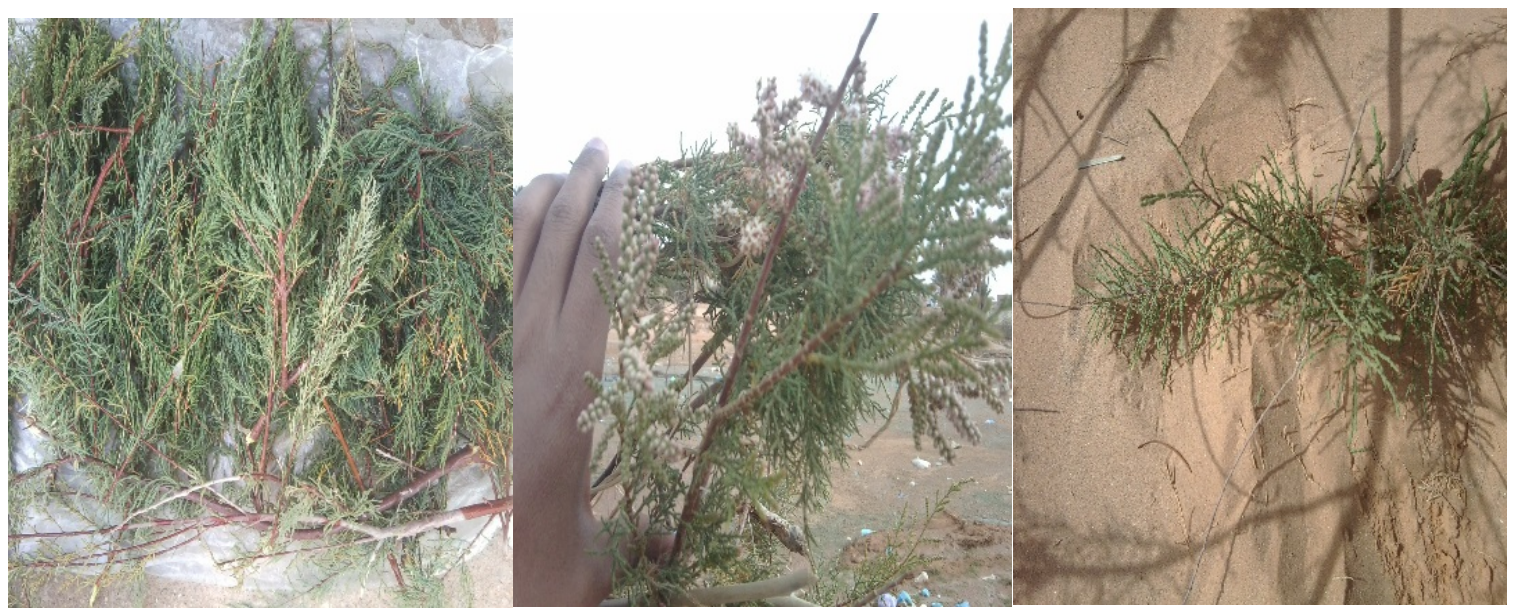

Figure 1. Tamarix gallica shrub located in the valley of Djenain Difallah, Bechar, Algeria.

Chemicals and materials: Hexane, ethyl acetate, nbutanol, ethanol, acetone and chloroform. Distilled water was used throughout.

\section{Plant material sample to remove greasy substances:}

In a mount of Soxhlet, we introduced 45g (Note: you can increase the mass if you want to have an important yield) of plant material in the presence of $150 \mathrm{ml}$ of hexane/petroleum ether are brought to reflux for 2 to 3 hours. After evaporation of solvent, an oily residue of green-black color is obtained (figure 2) [6-7].
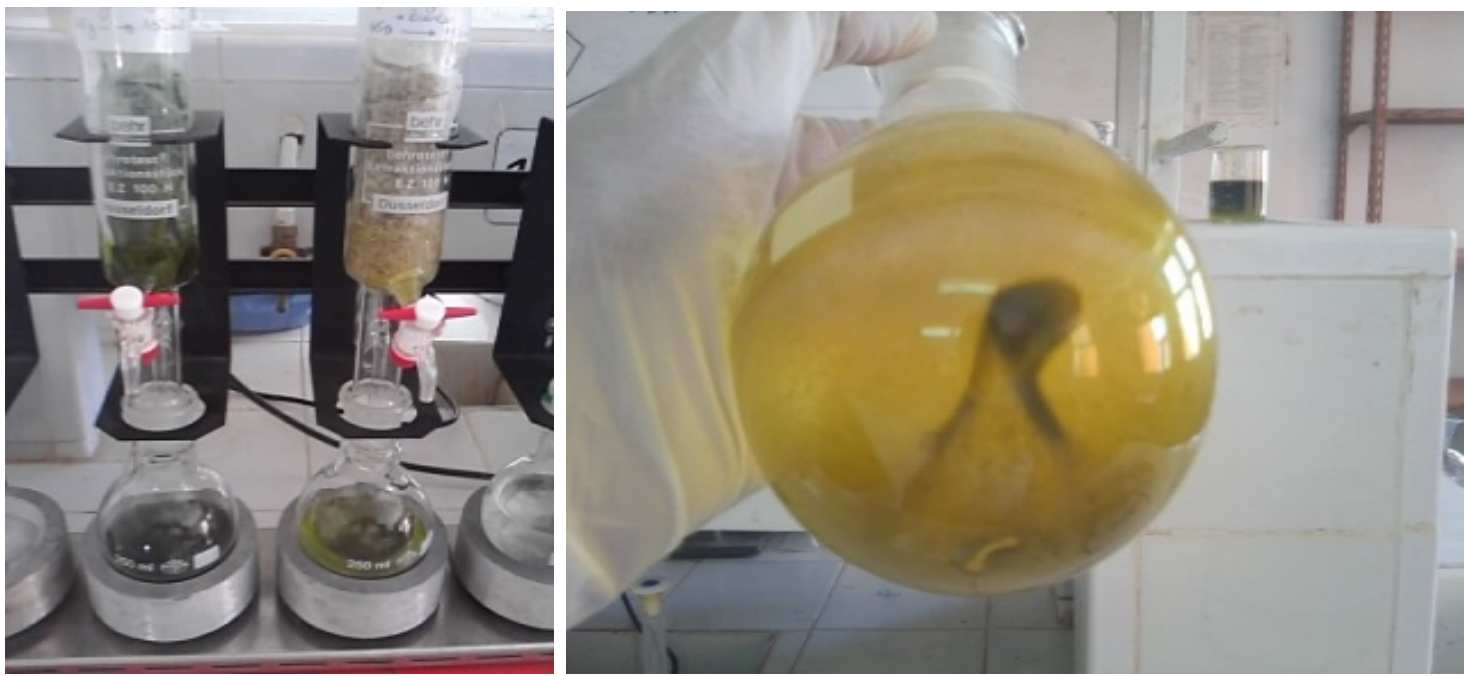

Figure 2. Plant material sample during its greasy substances removing.

Extraction process of flavonoids: In this part work, we chose to follow flavonoids as bioactive substances 
from the leaves of Tamarix gallica extraction method, which it submitted under two experimental procedures below:

Procedure A: In a flask, $45 \mathrm{~g}$ of plant dried and chopped material were added, then we added per
$270 \mathrm{ml}$ of mixture (water-acetone) of proportion (90; $180 \mathrm{ml}$ ) respectively. The flask was placed with its contents in the fitting of extraction to reflux and left for the extraction takes place over six hours. After, the extract undergoes a filtration to get the crude plant material [8-9].

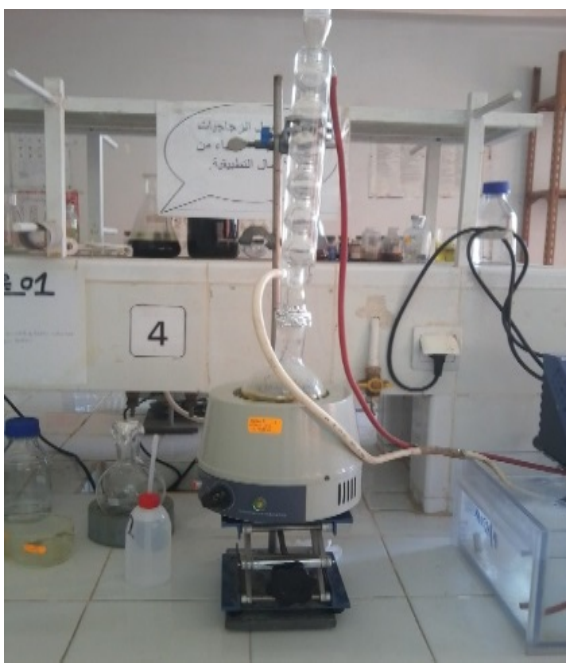

Figure 3. Plant material sample during extraction by Reflux process.

Procedure B: The aqueous extract obtained after the solid-liquid extraction is followed by liquid-liquid extraction respectively by two solvents: ethyl acetate, n-butanol. In a separator funnel, the aqueous extract obtained was added. After that we added $30 \mathrm{ml}$ of solvent followed by a stirring for 5 minutes, paying attention to liberate the separator funnel from time to time. After that, it was allowed to the rest until the separation is possible [10-11]. It collects the denser phase (aqueous phase) and it collects the phase of less dense (solvent phase). The process is repeated three times and the phases of each solvent are collected and evaporated (recovery of solvent) using a vacuum [12-13].
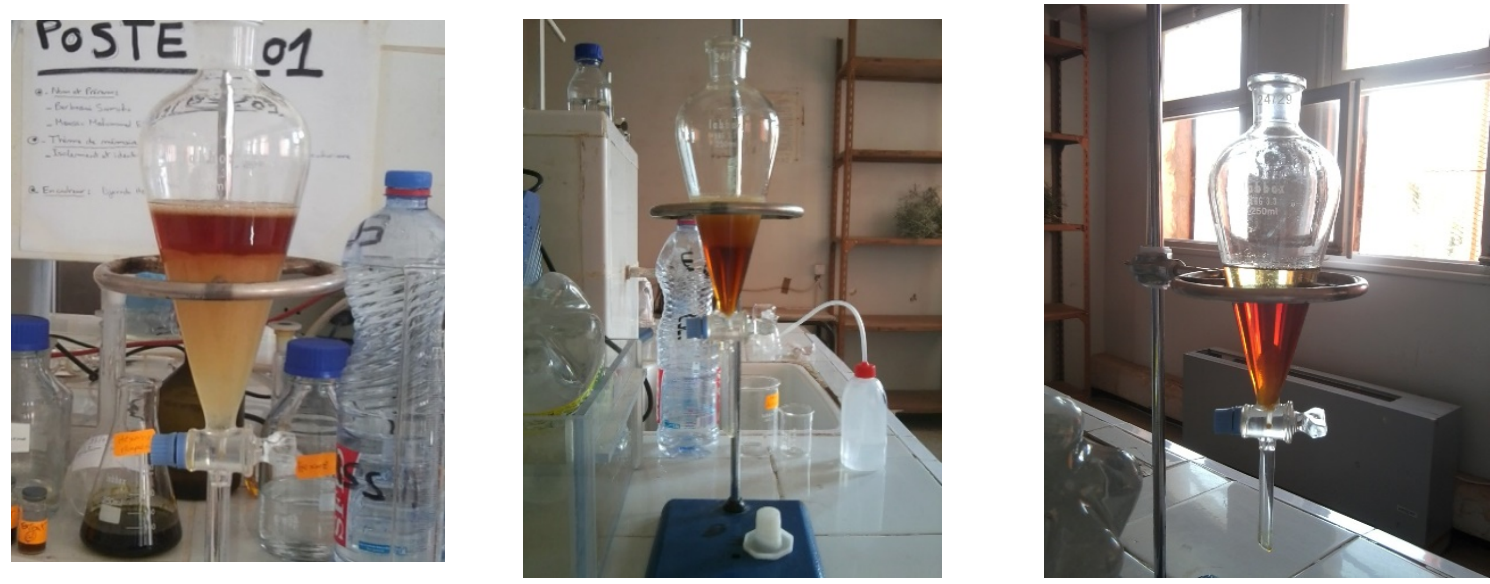

Figure 4. Liquid-Liquid Extraction of plant material crude using by two solvents: ethyl acetate, n-butanol.

Identification of extracted compounds: The products were analyzed with TLC chromatography and spectroscopy methods (UV, IR and NMR). UV spectra were obtained with SPECORD ${ }^{\circledR} 50$ uv- 
visible spectrophotometer. IR spectra were obtained with a Bruker Alpha FT-IR spectrometer, The NMR spectra were taken on a Bruker GP $300 \mathrm{MHz}$

\section{RESULTS AND DISCUSSION}

Crude flavonoids extracted from leaves of Tamarix gallica has weight with $0.95 \%$ from ethyl acetate extract and $4.31 \%$ of n-butanol extract.

Table 1. Various Extracts of Tamarix gallica Leaves and their Physical form.

\begin{tabular}{|c|c|c|c|c|c|}
\hline SI.No & solvent & Consistency & Color & Odor & Extractive Value (\% w/w) \\
\hline 1 & $\begin{array}{c}\text { Ethyl } \\
\text { acetate }\end{array}$ & solid & Yellow & higher & 0.95 \\
\hline 2 & n-butanol & solid & Brown & higher & 4.31 \\
\hline
\end{tabular}

\section{Removing \\ greasy \\ materials}

\section{liquid-liquid by ethyl acetate}

\section{Flavonoïd Crude}

\section{Solvant-} Extraction

\section{liquid-liquid by $n$-butanol}

Figure 5. Four keys properties of solvent-extraction system of medicinal plants from Tamarix gallica.

TLC Chromatography analysis: Flavonoids extracted from Tamarix gallica leaves were chromatographed over Silica gel, eluting with ethyl acetate /chloroform/hexane (6.5:3:0.5) Rf: 0.87 for ethyl acetate extract and for $n$-butanol extract $R_{\mathrm{f}}: 0.88[14-$ 15].

Table 2. TLC chromatography results of two crudes extracted from Tamarix gallica leaves.

\begin{tabular}{|c|c|c|c|c|c|}
\hline Mass (g) & \multirow[t]{2}{*}{ solvent } & \multicolumn{4}{|c|}{ (6.5/3/0.5) acetic acid/CHCl3/hexane } \\
\hline \multirow{3}{*}{45} & & Rf \% & Color of spot & UV $\lambda(\mathrm{nm})$ & $\mathrm{I}_{2}$ room \\
\hline & Ethyl acetate & 0.87 & $\begin{array}{c}\text { Purple/yellowish } \\
\text { green }\end{array}$ & $254 / 365$ & Light brown \\
\hline & n-butanol & 0.88 & $\begin{array}{c}\text { Purple/yellowish } \\
\text { green }\end{array}$ & $254 / 365$ & Dark brown \\
\hline
\end{tabular}




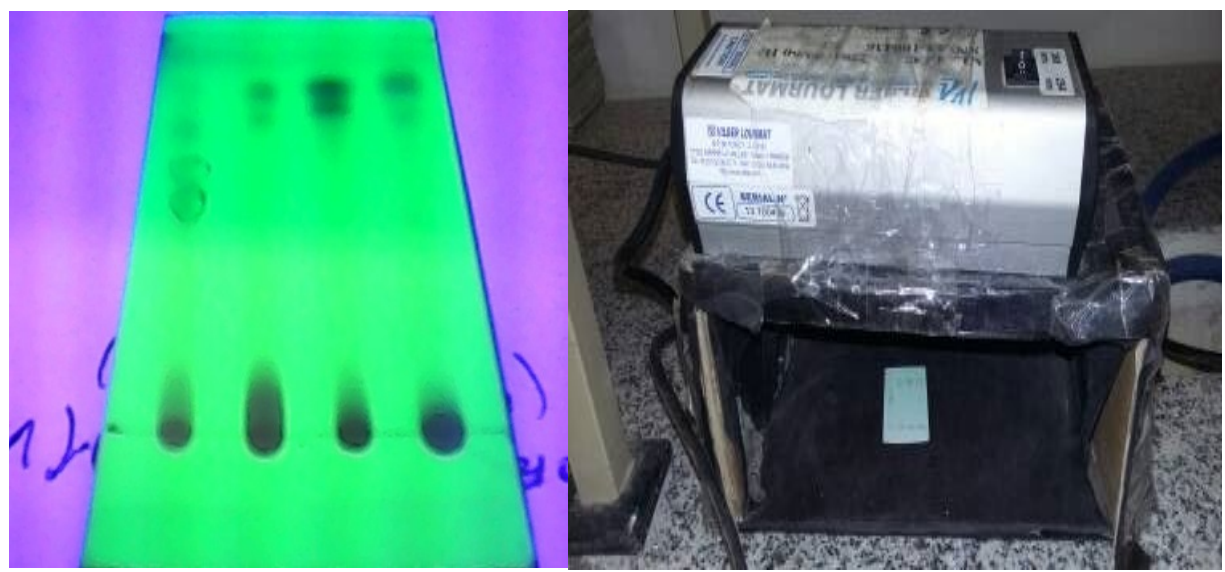

Figure 6. TLC Chromatogram of three extracts obtained using by elution system (EtOAc $/ \mathrm{CHCl} 3 / \mathrm{hexane}$ ).

Spectroscopy analysis using by UV, IR and $\mathrm{NMR}^{\prime 1} \mathrm{H}$ :

Flavonoids extracted from Tamarix gallica were identified by spectroscopy methods [16]. The UV spectrum of the ethyl acetate crude in chloroform showed maximum absorption at 244, 269, 325 and 365 nm (figure. 5) [17-19].

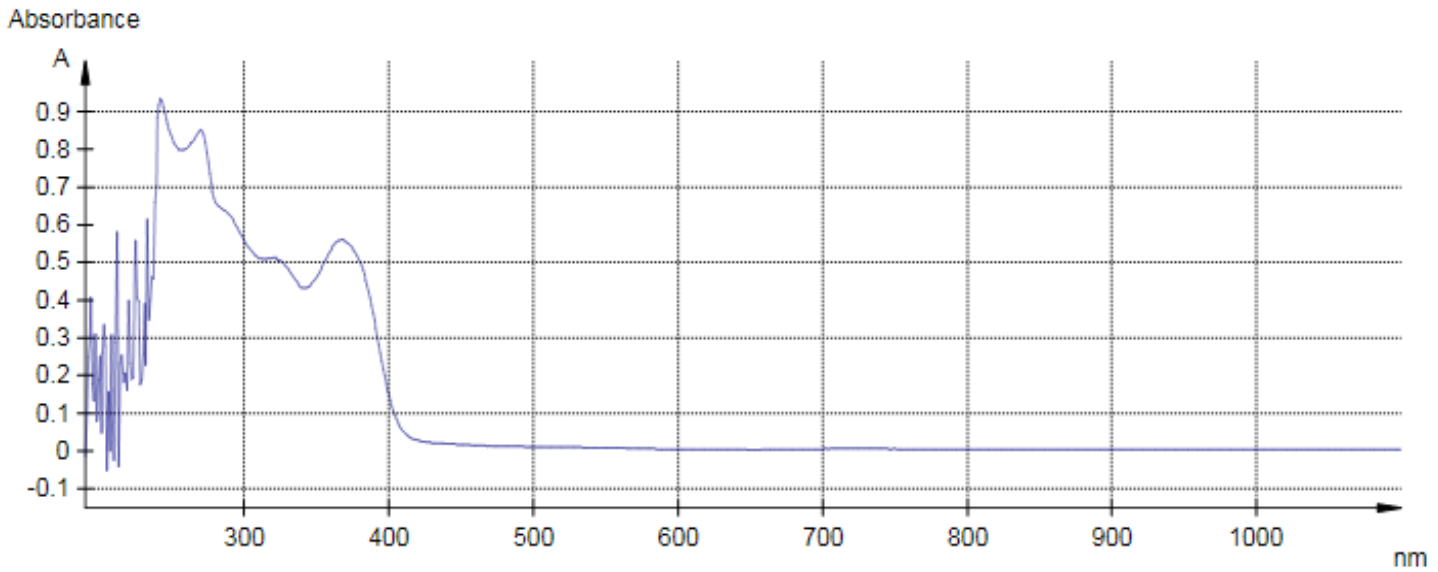

Figure 7. UV spectrum of crude extracted by ethyl acetate.

For n-butanol crude in distilled water showed maximum absorption at 210, 267 and $352 \mathrm{~nm}$ (figure. 6) [20-23].

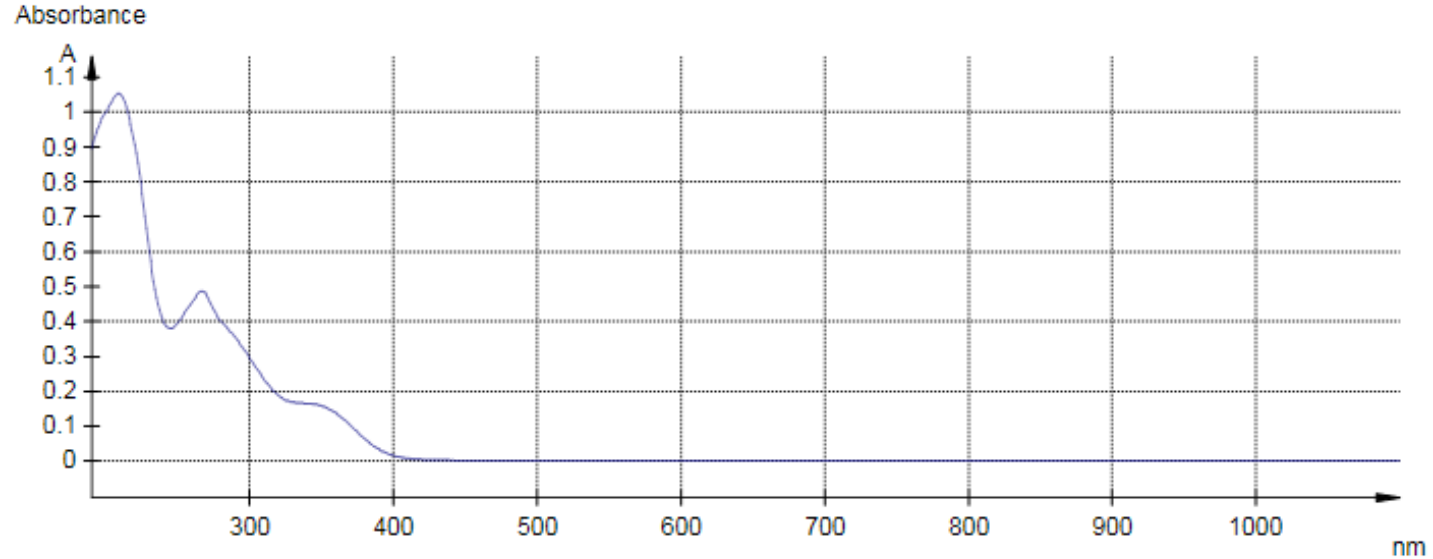

Figure 8. UV spectrum of crude extracted by n-butanol.

Table 3. Two crude extracts of plant material from Tamarix gallica leaves by IR spectroscopy analysis. 


\begin{tabular}{|c|c|c|}
\hline \multirow[t]{2}{*}{ Wavenumber IR (cm-1) } & \multicolumn{2}{|c|}{ Extracted compounds } \\
\hline & Ethyl acetate crude & n-butanol crude \\
\hline vO-H & 3612 & 3648 \\
\hline טO-H (associate) & 3235 & 3211 \\
\hline $\mathrm{uC}=\mathrm{C}-\mathrm{H}$ (aromatic) & $3050-3100$ & $3050-3100$ \\
\hline $\begin{array}{c}\mathrm{uL-H} \\
\text { intramolecular }\end{array}$ & 2355 & / \\
\hline $\begin{array}{c}\mathrm{u}-\mathrm{CH} 3 \\
\text { (asym/sym) }\end{array}$ & / & 2958 \\
\hline $\mathrm{vC}=\mathrm{O}(\alpha, \beta$ inst, aryl) & 1714 & 1716 \\
\hline uC=O (enol) & 1645 & 1646 \\
\hline $\mathrm{vC}=\mathrm{C}$ (aromatic) & $\begin{array}{l}1602 \\
1560 \\
1508 \\
1450\end{array}$ & $\begin{array}{l}1601 \\
1558 \\
1507\end{array}$ \\
\hline$\delta \mathrm{O}-\mathrm{H}$ & $\begin{array}{l}1350 \\
1312\end{array}$ & 1352 \\
\hline $\begin{array}{c}\delta-\mathrm{CH} 3 \\
\text { (asym/sym) }\end{array}$ & & 1446 \\
\hline טФ-O-C & 1279 & 1280 \\
\hline $\mathrm{UC}-\mathrm{OH}$ & 1177 & 1178 \\
\hline UC-O-C & 1029 & $\begin{array}{l}1067 \\
1033\end{array}$ \\
\hline$\vee C=C-O$ et $\vee C=C-C$ & $870,837,811$ & $937,870,837,811$ \\
\hline$\gamma \mathrm{C}=\mathrm{C}-\mathrm{H}$ et $\gamma-\mathrm{OH}$ & $754,670,641$ & $754,670,641$ \\
\hline
\end{tabular}

The infrared spectrum of ethyl acetate crude showed a strong band of $\mathrm{OH}$ at 3612 and $3235 \mathrm{~cm}^{-1}$, large bond of $\mathrm{CH}$ (aromatic) 3050-3100 $\mathrm{cm}^{-1}$, and $\mathrm{C}=\mathrm{O}(\alpha, \beta$ unsatured, acrylic) at 1714 and enolic form at 1645 $\mathrm{cm}^{-1}, \mathrm{C}=\mathrm{C}$ (aromatic) at 1602, 1560, 1508 and 1450 $\mathrm{cm}^{-1}, \mathrm{C}-\mathrm{O}$ strong bond at 1177 and $\Phi-\mathrm{O}-\mathrm{C}$ at $1279 \mathrm{~cm}^{-}$ ${ }^{1}$ [24-27].

The infrared spectrum of $n$-butanol crude showed a strong band of $\mathrm{OH}$ at 3646 and $3211 \mathrm{~cm}^{1}$, large bond of $\mathrm{CH}$ (aromatic) $3050-3100 \mathrm{~cm}^{-1}, \mathrm{CH} 3$ medium bond at $2958 \mathrm{~cm}^{-1}$, and $\mathrm{C}=\mathrm{O}(\alpha, \beta$ unsatured, acrylic) at 1716 and enolic form at $1646 \mathrm{~cm}^{-1}, \mathrm{C}=\mathrm{C}$ (aromatic) at 1601, 1558 and $1507 \mathrm{~cm}^{-1}, \mathrm{C}-\mathrm{O}$ strong bond at 1178 and $Ф$ $\mathrm{O}-\mathrm{C}$ at $1280 \mathrm{~cm}^{-1}$ [28-29].

$N R^{1} H$ flavonoids spectrum both of ethyl acetate extract and n-butanol crudes: Ethyl acetate crude: ${ }^{1} \mathrm{HNMR}\left(\mathrm{CDCl}_{3}, 300 \mathrm{MHz}\right) \delta 7.276(\mathrm{~s}, 1 \mathrm{H}), 2.065(\mathrm{~m}, 1 \mathrm{H})$ $1.646(\mathrm{~m}, 1 \mathrm{H}) 1.301(\mathrm{~m}, 1 \mathrm{H}) 0.923(\mathrm{~d}, 1 \mathrm{H}) 1.572(\mathrm{~s}, 1 \mathrm{H})$ 1.661(m, 1H). 
n-butanol crude: ${ }^{1} \mathrm{HNMR}\left(\mathrm{CDCl}_{3}, 300 \mathrm{MHz}\right) \delta$ 7.722(m, 1H), 7.546(m, 1H), 7.280(s, 1H), 4.137(q, $1 \mathrm{H}), 3.708(\mathrm{~m}, 1 \mathrm{H}), 3.430(\mathrm{~m}, 1 \mathrm{H}), 2.204(\mathrm{~m}, 1 \mathrm{H})$, 2.062(s, $1 \mathrm{H}), 1.420(\mathrm{~m}, 1 \mathrm{H}), 0.925(\mathrm{td}, 1 \mathrm{H}), 0.748(\mathrm{~m}$, $1 \mathrm{H})$.

It could be deduced that there is a deblinding: $\delta=$ $7.280,7.276 \mathrm{ppm}$ represent the presence of an aromatic cycle for the two extracted compounds.
N.B: the NMR spectrums were not well determined so you must increase plant material before the extraction procedure to get enough weight mass of extract crude.

From these interpretations of spectroscopic analysis UV, IR and $N M R^{1} H$, we can say that the isolated compounds ethyl acetate extract and nbutanol extract from leaves of Tamarix gallica probably are flavonols-substituted [28-31].

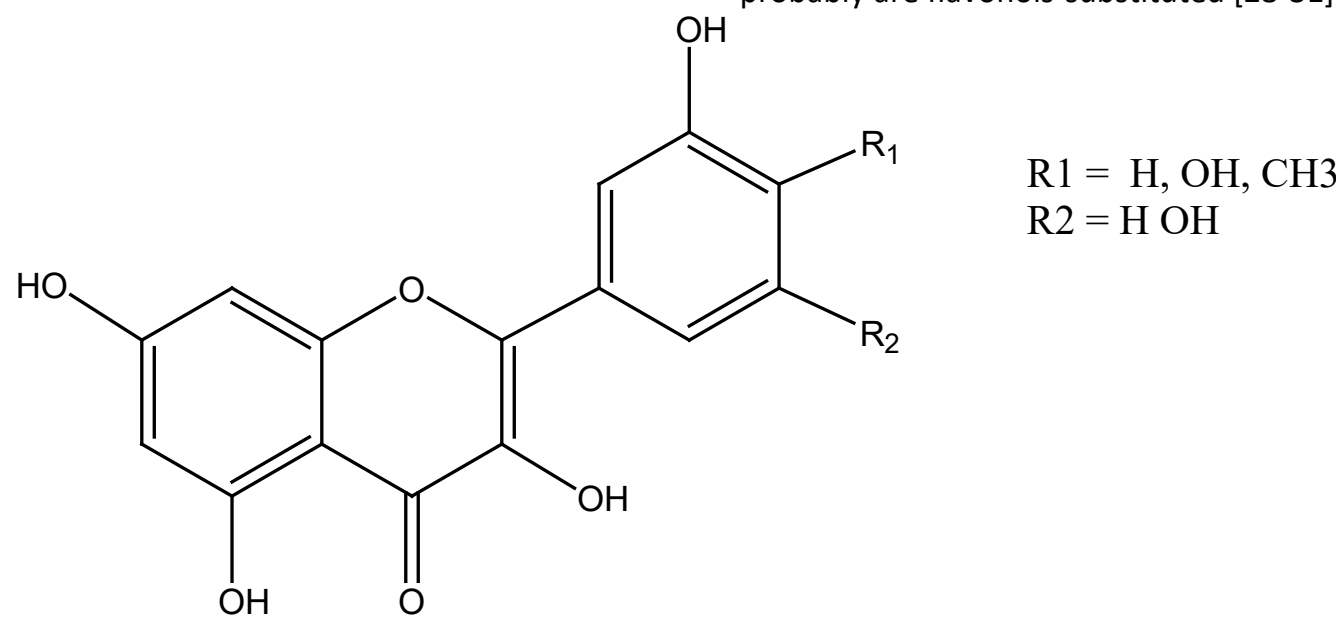

Figure 9. The Chemical Structure of Proposal Flavonols.

\section{CONCLUSION}

The extraction and separation of bioactive substances from the leaves of Tamarix gallica, were obtained. These compounds have been in a pure state by useful protocol of extraction combined with the chromatographic analysis. The identification of these bioactive substances separated is made by the methods of spectroscopy analysis such as UV, IR, and $\mathrm{NMR}^{1} \mathrm{H}$ that allow the determination of probable structures of extracted compounds.

In the light of these results, the methods of the UV and the IR reveal bands characteristics it has happened to propose that the bioactive substances that we isolated in this work are flavonoid type of flavonol-extracted compounds.

List of Abbreviations used: UV; Ultraviolet, IR; Infrared, NMR; Nuclear Magnetic Resonance, Rf; reference factor, EtOAc; ethyl acetate, $\mathrm{CHCl}$; chloroform, inst; instauration, asym; asymmetric, sym; symmetric, TG; tamarisk gallica. TLC; This Layer Chromatography, $\mathrm{CDCl}_{3}$; Deuterated Chloroform, $\mathrm{MHz}$; megahertz.

Competing interests: There are no competing interests in this study.

Authors' Contributions: Moussa Mohammed Elamin; designed the research, conducted the experiments and spectroscopy analysis and wrote the manuscript. I have read and approved the final version of the manuscript.

Acknowledgment and funding: This research work would not have been possible without the support of many people. The author wishes to express her gratitude to her supervisor, with her assistant who 
was abundantly helpful and offered invaluable assistance, support and guidance. Special thank also to Faculty of Exact Sciences Laboratory of Tahri Mohammed university Bechar, Algeria No. 08000 and we don't forget the University of science and technology of Oran - Algeria especially the laboratory of NMR spectroscopy for his support the analysis there.

\section{REFERENCES}

1. P. Ozenda Flore and vegetation of the Sahara, $3^{\text {rd }}$ Edition, Editions of the national center of scientific research Paris, 2004: 342-344.

2. P. Ozenda Flore and vegetation of the Sahara. $3^{\text {rd }}$ Edition, Editions of the national center of scientific research Paris, 2004: 345-349.

3. Y. Belhadjadji. Extraction and identification of polyphenols of the Acacia Raddiana, $1^{\text {st }}$ Edition, Tahri Mohammed University, Bechar, 2007: 80-85.

4. Khaled Sekkoum, Nasser Belboukhari, Abdelkrim Cheriti. Asian Pacific Journal of Tropical Biomedicine. 2014; 4; 4: 261-267.

5. Salwa A. Kawashty, Sameh R. Hussein, Mona M. Marzouk, Lamyaa F. Ibrahim, Mohamed M. I. Helal and Sabry I.M. El Negomy. Journal of Applied Sciences Research 2012; 8(3): 1484-1489.

6. K R Markham. Techniques of flavonoid identification, $1^{\text {st }}$ Edition, Academic Press, London, 1982: 1-113.

7. N. Belboukhari, A.Cheriti. Spectroscopy analysis in organic chemistry, $2^{\text {nd }}$ Edition Collection El Ouloum, Algeria. 2013: 101-103.

8. N.Belboukhari, A. Cheriti. Spectroscopy analysis in organic chemistry, $2^{\text {nd }}$ Edition Collection El Ouloum, Algeria. 2013: 99-100.

9. N.Lahmer. Belboukhari. Cheriti. A. Hesperidin, Hesperetin, and purification from Citrus sinensis peels. Der "Pharma Chemica. 2015; 7; 2: 1-4.

10. M. Benahmed, S. Akkal, A. Elomri, H. Laouer, P. Verite, E. Seguin. Constituents from Bupleurum montanum (Coss. and Dur.) (Apiaceae) Arabian Journal of Chemistry. 2014; 1(7):1065-1069.

11. O. O. Aiyelaagbe, Paul $\mathrm{M}$ Osamudiamen Plant Sciences Research; 2; 1: 11-13.

12. H. O. Edeoga, D. E. Okwu, B. O. Mbaebie. African Journal of Biotechnology, 2005; 4; 7: 685-688.

13. V. Alagarsamy Pharmaceutical chemistry of naturel products, $1^{\text {st }}$ Edition, India Elsevier, India, 2012: 156.

14. Mehta Kavit, Patel B. N, Jain B. K. Research Journal of Recent Sciences, 2013; 2; 2: 12-15.

15. Jigna Parekh, Nehal Karathia and Sumitra Chanda. African Journal of Biomedical Research. 2006; 1; 9: 53-56.

16. Zeghad N. Study of the contents upon two medicinal plants of economic interest (Thymus vulgaris, Rosmarinus officinalis) and assessment of their antibacterial activity, $1^{\text {st }}$ Edition, University of Mentouri, Constantine, Algeria,2009; 41-42.

17. Ait Youssef M. Plantes médicinales de Kabylie, Editions Ibis Press, Paris, 2006: 349.

18. Albouy, V. The medicinal Garden, step by step: treat yourself with products from your garden, Editions de la Lesse, Aix-en-Provence, France, 2008: 95.

19. Andreas, B., Guide des plantes du bassin méditerranéen, édition Française, Les éditions Eugen Ulmer, 1998:400.

20. Anne-Sophie and Nogaret-Ehrhart, Phyto-therapy healing oneself with plants, Edition Groupe Eyrolles, Second edition 2006: 191.

21. Anton, R. and Wichtl, M. Therapeutic plants: tradition, pharmacy practice, science and therapy, 2 nd edition, Lavoisier, 2003: 692.

22. Baba Aïssa, F. Medicinal plants in Algeria, Co-edition Bouchène and Ad. Diwan, Algiers, 1991: 97.

23. Baba Aissa, F., Encyclopedia of useful plants, flora of Algeria and the Maghreb, copyright bookstore, Algiers, 1999: 368.

24. Beloued, A., Medicinal plants of Algeria, Edition office of publications universities, 2005: 284.

25. Bruneton, J., Pharmacognosy, phytochemistry, medicinal plants, Tec et doc Lavoisier edition, Paris, $3^{\text {rd }}$ edition, 1999: 1120.

26. Ardevol, A., Virgili, J., Sanchis, D., Adan, C., FernandezReal, J. M., Fernandez-Lopez, J. A., Remesar, X., and Alemany, M. A method for the measurement of plasma estrone fatty ester levels. Analytical Biochemistry, 1997; 249: 247-250.

27. Bergner-Lang, B, Kachele, M. Anabolika in Kalbfleisch Nachweis and Bestimmung, Befunde and Beobachtungen. Dutch. Lebensm. Rundsch, 1987; 77: 305-313.

28. Biedermann, M., Grob, K., and Mariani, C. Trans esterification and on-line LC-GC for determining the sum of free and esterified sterols in edible oils and fat. Fat Science Technology, 1993; 95: 127-138.

29. Bundesge sundheitsamt Arbeitsgruppe Anabolica niche $x$ 35 LMBG. Bestimmung von hormonell wirksamen Stoffen. (Anabolika) in Fleisch (Muskelgewebe), Leber, Niere and Fettgewebe (vorlaufige Method). Bundesgesundheitsblatt, 1989; 2: 76-80.

30. Feher, T, Borgia, L. A comparative study of steroid concentrations in human adipose tissue and the peripheral circulation. Clin. Chim. Acta. 1982; 126: 135141.

31. Fritsche, S., Schwarz, F. J., Kirchgebner, M., Augustini, C., and Steinhart, H. Influence of sampling on steroid hormone patterns of beef from bulls and steers. Meat Science, 1998; 50: 257-264. 